\title{
Introdução à conservação e restauro do azulejo
}

Quando pensamos em restaurar azulejos, há duas situaçð̄es a considerar porque vão definir, depois do restauro, a sua apresentação.

Assim, temos os azulejos que já foram retirados da arquitectura a que intimamente pertencem e, os azulejos que estão integrados.

Mesmo assim, ainda temos que considerar os azulejos assentes no exterior dos edifícios e, os azulejos assentes no interior.

Reportando-nos ao azulejo integrado na arquitectura, a sua saúde e longevidade está profundamente ligada à superfície de suporte (geralmente paredes) e, às argamassas utilizadas no seu assentamento.

Podemos mesmo dizer que, o azulejo além de reflectir calor e luz, reflecte também o estado de saúde das paredes.

Fundamentalmente (sejam quais forem as causas que a provoquem) é a humidade a grande causadora da deterioração das paredes e, consequentemente do azulejo. É por acção da humidade que se dá a expansão das paredes com desgregação dos elementos mal ligados; é por acção da humidade que se dá a cristalização de sais provenientes dos solos ou contidos nas argamassas de assentamento e que, ao eflorescerem provocam a queda do esmalte dos azulejos.

E evidente que nunca podemos considerar o restauro do azulejo integrado na arquitectura, sem que haja uma estreira colaboração com um arquitecto ou engenheiro civil que se ocupe da recuperação da parede, considerando sobretudo a eliminação das causas da humidade e não somente os efeitos.

Voltando ao restauro do azulejo integrado na arquitectura, frequentemente deparamos com dois casos mais comuns: ou se deu uma desagregação das massas de assentamento e o azulejo forma "barrigas» de maior ou menor extensão na parede, incorrendo consequentemente no risco de queda ou, a afloração dos sais já atravessou toda a camada de barro do azulejo, esbarrou de encontro à superfície vítrea (não porosa), formando primeiro umas pequenas «bolhas» e depois desprendendo o próprio esmalte.

Nestes casos, há que proceder-se ao levantamento dos azulejos do seu suporte inicial. O levantamento constitui um trabalho delicado no qual se deverá ter em conta sobretudo a conservação de cada uma das unidades uma vez que ao destacá-las da parede, o azulejo sofre com as vibraçðes das pancadas.

Consideramos massas de assentamento, as tradicionais, constituídas por cal e areia já que são por enquanto irrecuperáveis os azulejos assentes com cimento hidráulico ou cola de contacto.

Após o indispensável levantamento fotográfico dos conjuntos, procede-se à marcação das espécies que os constituem. Esta marcação é feita com uma letra e um número para cada unidade. As letras, por ordem alfabética, são apostas de baixo para cima, ordenando assim as fiadas horizontais e, os números da esquerda para a direita referem as fiadas verticais.

Esta marcação, feita sobre a face nobre, deverá ser indelével e resistente tanto às lavagens como ao manu. seamento. Assim, sendo escrita sobre uma pincelada de verniz acrílico e coberta por outra pincelada idêntica consegue-se facilmente o objectivo.

Procede-se depois à remoção cuidadosa dos excessos de argamassa aderentes ao tardóz do azulejo e ao seu acondicionamento em caixotes próprios de madeira, colocando-os face em face.

Sempre que um azulejo não saiu inteiro (muitas veze: por ter sido assente já partido), todos os fragmento: são recolhidos num saco de papel que ganha a sua referência.

Estes caixotes são etiquetados, com o número de ordem correspondente a uma ficha de levantamentc que refere as unidades nela contidas e o conjunto : que pertencem.

Uma vez no laboratório, acabam-se de remover todas as aderências tanto no tardóz como na face nobre (se as houver), procedendo-se depois à colagem dos azulejos fragmentados utilizando uma cola reversível mas, resistente à água tendo os cuidados indispensáveis pare que não provoque demasiado enchimento nas juntas. nem desnivelamento na superfície vidrada.

Os azulejos são depois lavados com um detergente neu. tro para não provocar reacçðes químicas indesejáveis. Procede-se então aos testes de identificação de sai incorporados. Esses sais podem ser solúveis ou insolúveis. É praticamente impossível encontrar azulejos retirados do seu suporte original que não acusem a presença de sais provenientes de infiltraçð̃es.

Após os sucessivos banhos em água desmineralizada, em que os azulejos ficam de um dia para o outro, essa água é analisada e renovada, diariamente, até que deixe de acusar qualquer presença de sais.

$\mathrm{O}$ azulejo só é enxuto quando se tiver a certeza de que não há nenhum ácido no seu interior e de que todos os sais formados durante o processo terão sido removidos. É preciso ter em conta que os sais insolúveis se convertem em sais solúveis, eventualmente reactivos.

Secam-se então os azulejos, numa estufa de secagem com ventilação cuja temperatura não exceda os $100^{\circ}$ centígrados, ficando assim os azulejos aptos para a recolocação.

No caso de haverem algumas faltas de azulejos, ou tendo estes grandes falhas de esmalte e que dificultem a leitura do painel ou repetição do padrão, é aconse-

\footnotetext{
a Técnica de Conservação e Restauro, Museu Nacional do Azulejo.
} 
lhável a reprodução desses azulejos, desde que haja elementos repetitivos e não se inventem interpretaçðes, sempre duvidosas. Por exemplo, se num painel figurativo faltam azulejos no emolduramento ou na cercadura, o tema está lá mas, se ao contrário nos faltam azulejos que constituem as figuras ou elementos descritivos da cena representada, sem haver fotografias antigas ou desenhos que garantam a sua veracidade é recomendável preencher essas falhas com azulejos sem desenho mas com o tom de cor dominante do painel. Quando as faltas são em grande quantidade ou se torna impossível o seu reassentamento opta-se geralmente por uma apresentação museológica em que os acidentes ficam à vista e, se conservam os restantes como documento.
No preenchimento de faltas de azulejos integrados na arquitectura, temos deparado com as soluçðes mais inacreditáveis. Desde encontrar azulejos do séc. XIX a preencher faltas em padrōes do séc. XVII, à baralhação de emendas feitas com azulejos de pintura a azul e branco, até às próprias fachadas em que muitas vezes se vêem dois ou três remendos de padrões diferentes, quase poderíamos dizer que é tão fertil a imaginação criadora nos revestimentos azulejares, como nas soluçð̌s de remendice, no remedeio das faltas.

No entanto, não há regras fixas para restauro devendo este adaptar-se a cada caso. Conforme, as condiçðes que se apresentam, assim se deverão propôr as soluçðes mais convenientes, tendo sempre em atenção o seu carácter garantidamente reversível. 